\title{
Experimental Plasmodium vivax infection of key Anopheles species from the Brazilian Amazon
}

\author{
Claudia M Rios-Velásquez ${ }^{1,8}$, Keillen M Martins-Campos ${ }^{5,7}$, Rejane C Simões ${ }^{3,4}$, Thiago Izzo ${ }^{6}$, \\ Edineuza V dos Santos ${ }^{3}$, Felipe AC Pessoa ${ }^{1}$, José BP Lima ${ }^{5,2}$, Wuelton M Monteiro ${ }^{5,7}$, Nágila FC Secundino ${ }^{8}$, \\ Marcus VG Lacerda ${ }^{5,7}$, Wanderli P Tadei ${ }^{3}$ and Paulo FP Pimenta ${ }^{5,8^{*}}$
}

\begin{abstract}
Background: Anopheles darlingi is the major malaria vector in countries located in the Amazon region. Anopheles aquasalis and Anopheles albitarsis s.l. are also proven vectors in this region. Anopheles nuneztovari s.l. and Anopheles triannulatus s.l. were found infected with Plasmodium vivax; however, their status as vectors is not yet well defined. Knowledge of susceptibility of Amazon anopheline populations to Plasmodium infection is necessary to better understand their vector capacity. Laboratory colonization of An. darlingi, the main Amazon vector, has proven to be difficult and presently An. aquasalis is the only available autonomous colony.

Methods: Larvae of An. darlingi, An. albitarsis s.l., An. nuneztovari s.l. and An. triannulatus s.l. were collected in the field and reared until adult stage. Adults of An. aquasalis were obtained from a well-established colony. Mosquitoes were blood-fed using a membrane-feeding device containing infected blood from malarial patients.

The infection of the distinct Anopheles species was evaluated by the impact variance of the following parameters:

(a) parasitaemia density; (b) blood serum inactivation of the infective bloodmeal; (c) influence of gametocyte number on infection rates and number of oocysts. The goal of this work was to compare the susceptibility to $P$. vivax of four field-collected Anopheles species with colonized An. aquasalis.

Results: All Anopheles species tested were susceptible to P. vivax infection, nevertheless the proportion of infected mosquitoes and the infection intensity measured by oocyst number varied significantly among species. Inactivation of the blood serum prior to mosquito feeding increased infection rates in An. darlingi and An. triannulatus s.l., but was diminished in An. albitarsis s.l. and An. aquasalis. There was a positive correlation between gametocyte density and the infection rate in all tests $(Z=-8.37 ; \mathrm{p}<0.001)$ but varied among the mosquito species. Anopheles albitarsis s.l., An. aquasalis and An. nuneztovari s.l. had higher infection rates than An. darlingi.

Conclusion: All field-collected Anopheles species, as well as colonized An. aquasalis are susceptible to experimental P. vivax infections by membrane feeding assays. Anopheles darlingi, An. albitarsis s.l. and An. aquasalis are very susceptible to $P$. vivax infection. However, colonized An. aquasalis mosquitoes showed the higher infection intensity represented by infection rate and oocyst numbers. This study is the first to characterize experimental development of Plasmodium infections in Amazon Anopheles vectors and also to endorse that P. vivax infection of colonized An. aquasalis is a feasible laboratory model.
\end{abstract}

Keywords: Plasmodium vivax, Anopheles, Malaria, Membrane feeding assay, Infection rate, Oocysts

\footnotetext{
*Correspondence: pimenta@cpqrr.fiocruz.br

${ }^{5}$ Fundação de Medicina Tropical Dr. Heitor Vieira Dourado, Manaus, AM, Brazil

${ }^{8}$ Centro de Pesquisas René Rachou, Fundação Oswaldo Cruz-Minas Gerais,

Av. Augusto de Lima, 1715, CEP 30190-002 Belo Horizonte, MG, Brazil

Full list of author information is available at the end of the article
} 


\section{Background}

Malaria is an infectious disease with major impact on global public health and economy. Currently, malaria threatens almost one third of the world population in 103 tropical countries, resulting in 207 million of clinical cases and 627,000 deaths in 2012 [1]. In the Americas, 21 countries are affected by malaria, with approximately 1.1 million cases in 2010, most of which occurred in the Amazon basin, which covers $40 \%$ of South American territory. In Brazil, the Federal Health System Surveillance registered 267,000 cases in 2011, most of them (99.8\%) in the Amazon region [2].

Human malaria parasites in the genus Plasmodium are transmitted by anopheline mosquitoes. Plasmodium falciparum and Plasmodium vivax are the main speciesaffecting humans. Actually, since the mid-1990s, P. vivax has become the predominant New World malaria species, as it has expanded its range throughout South America [1]. In Brazil, 84\% of registered malaria cases are caused by $P$. vivax [2]. The consequences of this increase in distribution are higher exposure and increased infection, adding to difficulties in controlling the disease. Although $P$. vivax malaria is generally considered to be relatively benign, there are numerous reports of complex cases with severe clinical complications and deaths [3-10].

One keystone stage in the Plasmodium life cycle is the infection of mosquito vectors. Among the 33 Anopheles mosquito species described from the Brazilian Amazon region, Anopheles darlingi is considered to be the main malaria vector. Other anopheline species can be considered secondary or occasional malaria vectors because of their population density, anthropophilic behavior and natural infectivity across their geographic distributions [11-14]. Anopheles albitarsis s.l., An. nuneztovari s.l. and An. triannulatus s.l. are commonly collected in the Amazon, and they have been observed infected with $P$. vivax and $P$. falciparum, but their role as malaria vectors has not yet been elucidated [15-25]. Anopheles aquasalis is distributed predominantly along the Atlantic coast because of its tolerance to saltwater environment and has been found naturally infected by $P$. vivax [20,26-28] in the Eastern Amazon region.

Outside the Brazilian Amazon, An. darlingi has been associated with malaria transmission in Bolivia, Colombia, French Guiana, Guyana, Peru, Suriname, and Venezuela [12,29]; An. albitarsis s.l. in Venezuela [30]; An. nuneztovari s.l. in Venezuela [30], Peru [31] and Colombia [32,33]; An. triannulatus s.l. in Venezuela [34] and Peru [31]; and, An. aquasalis in Trinidad [35], Guyana [28] and Venezuela, where it is considered to be the primary coastal malaria vector of $P$. vivax [36].

The life cycle of Plasmodium spp. starts when mosquitoes ingest gametocytes, the parasite sexual stage, during the blood meal taken through the skin of infected vertebrate hosts. Inside the mosquito alimentary tract, fusion between male and female gametocytes produces motile ookinetes, which traverse the mosquito midgut epithelium to form oocysts $[37,38]$. The presence of welldeveloped oocysts outside mosquito midgut indicates Plasmodium establishment in a susceptible vector and this parameter is used to determine the infection rate of a mosquito population $[39,40]$.

In the field studies, the infection rate, i.e., the amount of individuals in a mosquito population that carry welldeveloped Plasmodium oocysts, is an important parameter for defining vector competence and thus, a key indicator in the description of malaria dynamics and transmission biology in a given geographic region. Indeed, infection rates in mosquito vectors are related to gametocyte survival, viability and success of fertilization, and finally, midgut invasion by the resulting ookinetes. However, not all gametocytes that are ingested by susceptible mosquito vectors reach the ookinete stage [41-43]. Factors such as gametocyte density, gender ratio and maturity, presence of anti-malarial drugs, human and mosquito immune factors, and intrinsic parasite factors influence gametocyte viability, fusion and infectivity and consequently oocyst formation [44-48]. To complete the sexual development of Plasmodium in the mosquito, sporozoites are released from the oocyst and go on to invade the salivary glands. Once the salivary glands become infected with sporozoites, the mosquito is infectious to humans during the next blood meal [49-51].

It is well known that among the over 400 species of mosquitoes in the genus Anopheles only about $10 \%$ are important as vectors of human malaria. There is a multitude of both ecological and genetic determinants that influence vector competence, both among species and even at the level of geographic populations within a single species [41-45,47]. Differences in susceptibility to Plasmodium infection among the putative vectors of malaria in the Amazon have never been fully and carefully considered until this study.

Mosquito vectors of malaria from Africa and Asia have been well established in colonies and are feasible to maintain in laboratory. For example the Anopheles gambiae, the major vector in several African countries, is the most well studied mosquito, including its interaction with human and murine Plasmodium species causative agents of malaria [52,53]. Distinctly, the colonization of An. darlingi, the major Amazon vector, has proven to be difficult as well as other anopheline species from the region, and presently there is only An. aquasalis as an available autonomous colony. Anopheles aquasalis has been reared in laboratory as free mating since 1995 [54-56] and recently adapted as a well-established colony in Amazon institutions for experimental studies [57-59]. 
The goal of this work was to compare the susceptibility to $P$. vivax of colonized An. aquasalis with four groups of field-collected Anopheles species. This study was focused on vector infection rates as defined by the presence, quantification of oocysts and proportion (percentage) of infected individuals in these mosquito populations, following exposure to blood obtained from infected human patients. In addition, $P$. vivax infection in the vector was correlated with gametocyte numbers present in the circulating blood of infective human hosts. In laboratory studies, the infection rate is a critical part of the determination of vector competence. It is important to study $P$. vivax infection of New World vectors due to the huge gap regarding the knowledge comparing other vector-parasite pairs from the Old World.

\section{Methods}

\section{Blood collection and ethic statements}

Adult volunteers (ages $>18$ years) residents from the region of Manaus (State of Amazonas, Brazil) with $P$. vivax malaria infection diagnosed by blood smears were invited to participate in the study. Volunteers signed informed consent documents as blood sample donors. About $3 \mathrm{ml}$ of blood samples were collected by venipuncture from volunteers and placed into a sterile lithium heparinate vacutainer tube. After blood collection, all patients were treated at the Fundação de Medicina Tropical Dr Heitor Vieira Dourado (located in the city of Manaus) or in the health posts from the region of Manaus where they were diagnosed, following ethical procedures determined by the Brazilian Health Ministry. This study was approved by the Brazilian National Ethics Committee Board (CONEP, 3726).

\section{Plasmodium vivax peripheral parasitaemia and gametocyte counts}

Thick and thin blood smears from malarial patients were prepared by Giemsa staining method and examined under light microscope x100 oil immersion lens to confirm the presence of $P$. vivax parasites. Sexual (gametocyte) and asexual stages counting per 500 leukocytes were performed.

\section{Anopheles collections}

Mosquito larvae were collected during one year at different breeding sites near the city of Manaus, capital of Amazonas State, Brazil: Puraquequara Road (Portela 0303' 16.4"S 59 53'44.0"W; Km 9 Vicinal 0303'09.1"S 59 52' $12.6^{\prime \prime W}$; Carlão 03 02' 46.33000" 59 52' 53.90000"); Brasileirinho Road (Raifram 0302'09.5"S 5952'15.5"W; Cristo Vive $\left.03^{\circ} 01^{\prime} 33.1^{\prime \prime} \mathrm{S} 59^{\circ} 51^{\prime} 07.7^{\prime \prime} \mathrm{W}\right)$. Larvae were reared in the insectary as described elsewhere [17]. Emerged adult mosquitoes were identified as the following species: An. darlingi, An. albitarsis s.l., An. nuneztovari s.l. and An. triannulatus s.l., as described elsewhere [60,61]. Field mosquitoes from each species were separated and housed in the rearing containers. Anopheles aquasalis mosquitoes originated from a colony established in 1995 [54] were reared from eggs to adult. All mosquitoes were ad libitum fed 10\% sugar solution and kept in laboratory conditions at $26-28^{\circ} \mathrm{C}$ and $70-80 \%$ RH (relative humidity). Three- to five-days old adult females were used in all experiments. Pinned voucher specimens were deposited at the Biological Collection at the Instituto Leônidas e Maria Deane (Fiocruz, Amazonas).

\section{Plasmodium vivax infection of mosquitoes via membrane feeding assay}

Adult mosquitoes were sugar starved overnight prior to infection via membrane feeding assay. Individuals from each of the five species were separated in two experimental groups. One group was offered whole blood (WB) from P. vivax patients for a period of 45 to $90 \mathrm{mi}-$ nutes via membrane feeding assay (glass device covered with Parafilm ${ }^{\circ}$ ). Blood was held at $37-39^{\circ} \mathrm{C}$ through a hose system connected to a thermal bath. The second group was treated in similar way but with inactivatedblood serum (IBS). The P. vivax infective blood samples were centrifuged for 15 minutes at $2,000 \mathrm{~g}$ and the serum removed and heated for 1 hour at $56^{\circ} \mathrm{C}$. Then, the inactivated serum was added back to the red blood cells containing parasites, suspended and offered to the mosquitoes. After the infective blood meals only fully engorged mosquitoes were transferred to rearing containers and maintained in the insectary as described above for the development of infection.

\section{Evidence of infected mosquitoes}

Five to eight days after infective blood meal, midguts from the experimentally infected mosquitoes were dissected in phosphate buffered saline, stained with $2 \%$ commercial Mercurochrome (Merbromin), placed under a coverglass and examined for the presence of oocysts. The number of oocysts on the mosquito midgut was recorded.

\section{Data analysis}

In this study, the blood-feeding rate was calculated as the proportion of female mosquitoes that were fully engorged after a blood meal. The susceptibility of the Anopheles species to $P$. vivax was evaluated by the presence and the number of oocysts in the midguts. The population infection rates were calculated by dividing the number of infected mosquitoes (those with one or more oocysts) by the number of dissected mosquitoes. G tests were used to compare the frequency of infection among all the studied mosquito species conjointly, as 
well as pairwise comparisons between each pair of species. The Kruskal-Wallis test evaluates differences in the number of oocysts between the infected mosquito species. Only positively infected mosquitoes were used for this last analysis. Conover-Inman test, a posteriori, was used for comparison of the number of oocysts among all studied mosquito species [62,63]. For each mosquito species, logistic regressions were used in order to evaluate if the probability of the mosquito to be infected was related to the number of gametocytes in the blood meal. Spearman's Rank correlations were used in infected mosquitoes to correlate blood-circulating gametocyte numbers with oocyst numbers. G tests were used to compare the number of oocysts per infected midgut with the gametocytes present in the infective blood. G test was also used to evaluate if blood factors affect the mosquito infection probability, comparing the mosquito infection rate of the species fed on WB or ISB blood samples. All statistical analysis used $\alpha=0,05$ and the RProject software version 2.13.1 (R Core Team).

\section{Results}

A total of 2,449 adult female mosquitoes and $62 P$. vivax isolates from malarial patients were used for the different experimental feeding assays and only the fully engorged mosquitoes after blood feeding were analyzed in this study (Table 1). The five mosquito species differed in regard to feeding time until engorgement. Anopheles aquasalis, An. darlingi and An. triannulatus s.l. fed the most rapidly with $64 \%$ of individuals fed to repletion in 40 minutes. Anopheles albitarsis s.l. and An. nuneztovari s.l. fed more slowly, with $72 \%$ and $64 \%$, respectively, fully engorged over a period of approximately 60 to 80 minutes. The proportion of infected mosquitoes following engorgement on an infected blood meal was significantly different among species $(\mathrm{G}=199.1, \mathrm{GL}=4$, p <0.001) (Figure 1). Anopheles aquasalis and An. albitarsis s.l. showed very similar infection rates $(\mathrm{G}<0.01$, $\mathrm{GL}=1, \mathrm{p}=0.98)$. Actually, An. aquasalis showed the highest infection rate $(44.8 \%$, remaining comparisons, G $>18, \mathrm{GL} .=1, \mathrm{p}<0.001)$ followed by An. albitarsis s.l. (44.7\%), which were significantly different to all other mosquito species $(\mathrm{G}>8.14, \mathrm{GL}=1, \mathrm{p}<0.01)$. Anopheles nuneztovari s.l. held the third highest infection rate (24.5\%), and it was not statistically different to $A n$. darlingi, which had an infection rate of $18.3 \%(\mathrm{G}=2.1, \mathrm{GL}$ $=1, \mathrm{p}=0.148$ ), but was different to An. triannulatus s.l., with only $8.8 \%$ of the individuals infected $(\mathrm{G}=14.6, \mathrm{GL}$ $=1, \mathrm{p}<0.001)$. Anopheles darlingi also had a significantly higher infection rate compared with An. triannulatus s.l. $(\mathrm{G}=13.1, \mathrm{GL}=1, \mathrm{p}=0.001)$ (Figure 1).

The intensity of infection, measured by the numbers of oocysts per infected mosquitoes, fed on WB and IBS varied significantly among species $(\mathrm{K}=48.9, \mathrm{GL}=4, \mathrm{p}<$ 0.001 ) (Figure 2). The highest number of oocysts was observed in An. aquasalis (mean $=28.6 \pm 41.7$ S.D, median =12) and showed statistical difference when compared with all the other species. Anopheles darlingi (mean $=15.9 \pm 24.3 \mathrm{SD}$, median $=7)$ was followed by $A n$. albitarsis s.l. $($ mean $=13.3 \pm 14.8 \mathrm{SD}$, median $=6)$ and An. nuneztovari s.l. $\quad($ mean $=7.3 \pm 8 \quad \mathrm{SD}, \quad$ median $=5)$. There was no significant difference in the number of oocysts between An. darlingi, An. albitarsis s.l. and An. nuneztovari s.l. However, An. triannulatus s.l. had significantly less oocysts than all other studied species $($ mean $=3.4 \pm 4.7$ S.D., median $=1)$.

To outline the distribution of infection intensities, among WB-infected mosquitoes, we organize the oocyst

Table 1 Infection rate and mean number of oocysts produced in Anopheles species from the Brazilian Amazon infected with whole blood (WB-infected mosquitoes) or inactivated blood serum (IBS-infected mosquitoes)

\begin{tabular}{lcccc}
\hline $\begin{array}{l}\text { Anopheles } \\
\text { species }\end{array}$ & $\begin{array}{c}\text { Number of gametocytaemic } \\
\text { samples }\end{array}$ & $\begin{array}{c}\text { Number of dissected } \\
\text { gut }\end{array}$ & $\begin{array}{c}\text { Infection rate } \\
\text { WB-infected mosquitoes }\end{array}$ & $\begin{array}{c}\text { Mean number of oocysts (Min - } \\
\text { Max) }\end{array}$ \\
\hline An. albitarsis s.l. & 29 & 861 & 44,8 & $29,4(1-260)$ \\
An. aquasalis & 12 & 76 & 44,7 & $12,8(1-50)$ \\
A. darlingi & 17 & 530 & 18,3 & $15,9(1-150)$ \\
An. nuneztovari s.l. & 17 & 106 & 24,5 & $7,3(1-34)$ \\
An. triannulatus s.l. & 20 & 260 & 8,8 & $3,3(1-22)$ \\
\hline & 10 & IBS-infected mosquitoes & $22,5(1-200)$ \\
\hline An. albitarsis s.l. & 9 & 201 & 40,8 & $5,5(1-17)$ \\
A. aquasalis & 9 & 40 & 20 & $11,9(1-124)$ \\
An. darlingi & 9 & 217 & 28,1 & $11,5(1-80)$ \\
An. nuneztovari s.l. & 10 & 43 & 30,2 & $5,4(1-29)$ \\
An. triannulatus s.l. & 10 & 115 & 16,5 & \\
\hline
\end{tabular}

Ooc = oocysts, Min = minimal number of oocysts, Max = maximal number of oocysts. 


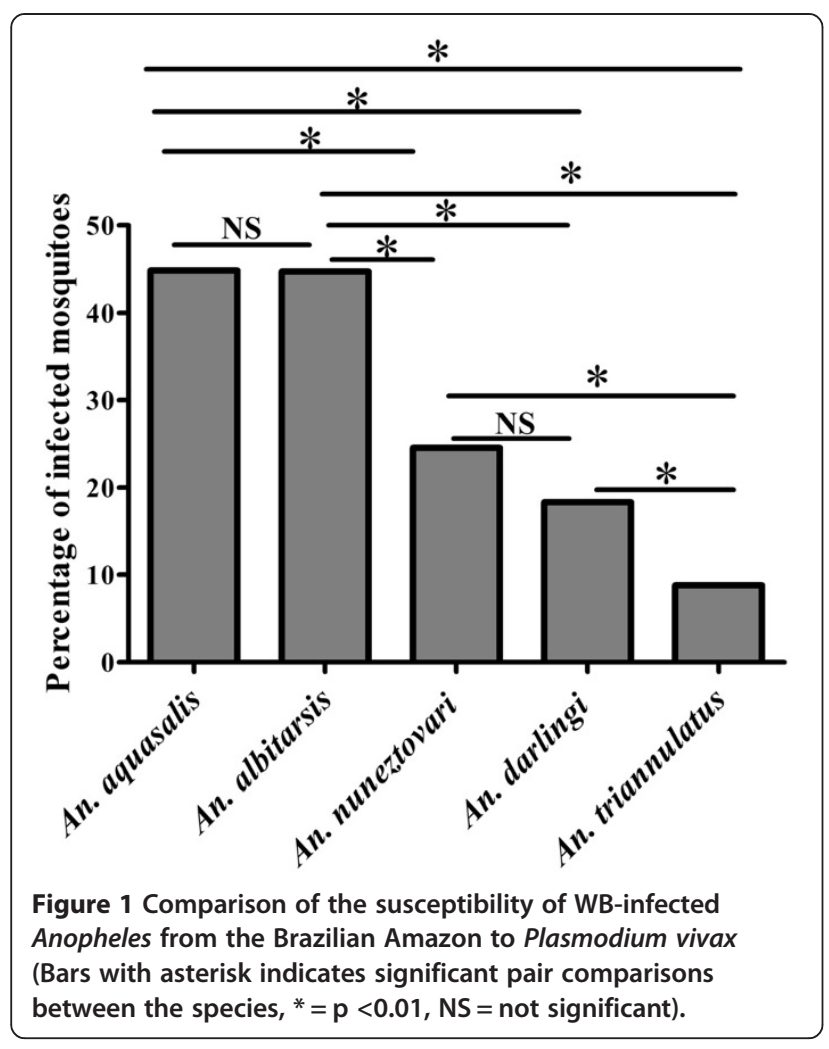

numbers into four groups, as follows: $1-10,11-50,51-$ 100 , and more than 100 oocysts. A comparison of the distribution of these groups among individuals within species is illustrated in Figure 3. Sixty-nine per cent of the mosquito specimens did not develop oocysts: the proportion of individuals with zero oocysts was higher in An. triannulatus s.l., followed by An. darlingi, An. nuneztovari s.l., An. aquasalis, and An. albitarsis s.l. Approximately $16 \%$ of individuals from all five species were infected with 1 to 10 oocysts and only $10 \%$ were infected with 11 to 50 oocysts, with the lower number of infected individuals observed in An. triannulatus s.l. (0.4\%) and the higher in An. albitarsis s.l. (21.3\%). Only An. darlingi and An. aquasalis had more than 50 oocysts, with 1.3 and $7.6 \%$ of the individuals, respectively.

Considering all the studied Anopheles species as a whole group, the inactivation of factors present in blood serum was not of significant importance to change the infection rate $(\mathrm{G}=0.2899, \mathrm{GL}=1, \mathrm{p}=0.585)$. However, the pattern of the infection rate differed among IBS-infected mosquito species. While the serum inactivation did not cause changes in infection rates on An. aquasalis $(\mathrm{G}=1.08$, $\mathrm{GL}=1, \mathrm{p}=0.298)$ and An. nuneztovari s.l. $(\mathrm{G}=0.5, \mathrm{GL}=1$, $\mathrm{p}=0.47$ ), serum inactivation resulted in a $53 \%$ increase in infection rates in An. darlingi ( $\mathrm{G}=8.55, \mathrm{GL}=1, \mathrm{p}=0.003$ ), and $87 \%$ increase in An. triannulatus s.l. $(\mathrm{G}=4.4, \mathrm{GL}=1$, $\mathrm{p}=0.035$ ). Inversely, the infection rate for An. albitarsis s.l. decreased by $55 \%(\mathrm{G}=7.32, \mathrm{GL}=1, \mathrm{p}=0.007)$ (Figure 4).
In general, the intensity of infection, represented by oocyst numbers, varied among species when inactivated serum was used to infect mosquitoes (IBS-infected mosquitoes). There was no difference in oocyst numbers formed on An. aquasalis $(\mathrm{U}=1.3, \mathrm{p}=2.44)$ and $A n$. nuneztovari s.l. (Mann-Whitney $\mathrm{U}=0.466 \mathrm{p}=0.495)$. On the other hand, the inactivation slightly increased the oocyst formation on An. triannulatus s.l. $(\mathrm{U}=7.7, \mathrm{p}=0.006)$ and decreased in An. darlingi $(\mathrm{U}=5.01, \mathrm{p}=0.024)$ and $A n$. albitarsis s.l. $(\mathrm{U}=8.27 ; \mathrm{p}=0.004)$ (Figure 2).

A total of $17 P$. vivax isolates from malarial patients were used for $A n$. darlingi feeding experiments, 13 for $A n$. albitarsis s.l., 17 for An. nuneztovari s.l., 20 for An. triannulatus s.l. and 29 for An. aquasalis (Table 1). Infection rates and range of oocyst numbers per gut varied widely among the different species of WB-infected mosquitoes and IBS-infected mosquitoes. In general, a relationship between the number of gametocytes/500 leukocytes and the infection rate of the mosquitoes $(\mathrm{Z}=-8.37, \mathrm{p}<0.001)$ was observed. However, that relationship varied among the species. For An. darlingi $(\mathrm{Z}=-2.9, \mathrm{p}<0.01)$ and An. aquasalis $(\mathrm{Z}=-4.66, \mathrm{p}<0.001)$ infection rates increased with an increase in the number of gametocytes. For An. nuneztovari s.l., An. triannulatus s.l. and An. albitarsis s.l. $(\mathrm{Z}<$ $1.02, \mathrm{p}>0.3$ in all cases) there was no correlation between those two variables. Also, among infected species, $A n$. aquasalis (Spearman rho $=0.255, \mathrm{n}=386, \mathrm{p}<0.01$ ) and An. darlingi ( $\mathrm{rho}=0.518 ; \mathrm{n}=54, \mathrm{p}<0.01$ ) showed a positive correlation between the number of gametocytes and the number of oocysts formed. The data for all other species did not exhibit a correlation between the quantity of gametocytes and the quantity of oocysts ( $p>0.05)$.

\section{Discussion}

The number of field mosquito specimens available for experimental infection was limited by the seasonality of the species and the malaria transmission peaks in the Amazonas region near to Manaus city. A membranefeeding assay was used to infect Anopheles species. Experimental infection of mosquito vectors can involve direct feeding on the skin of patients or offering blood meal through a membrane-feeding device. Ethical preference tends to lean towards the use of membrane-feeding experiments, in order to minimize the human factor interaction. Most experimental results with Amazon outbred Anopheles species have used direct skin feeding on gametocytaemic malarial patients $[17,27,64]$. These findings are in agreement with other published data where both direct and membrane feeding using blood from $P$. vivax-gametocytaemic patients resulted in An. darlingi infection rates between 22 and $23 \%$ with a mean oocyst load per infected midgut of 11.5 with a range of 1-175 $[65,66]$. Anopheles aquasalis and An. albitarsis s.l. had a significantly higher infection rate than $A n$. darlingi, 


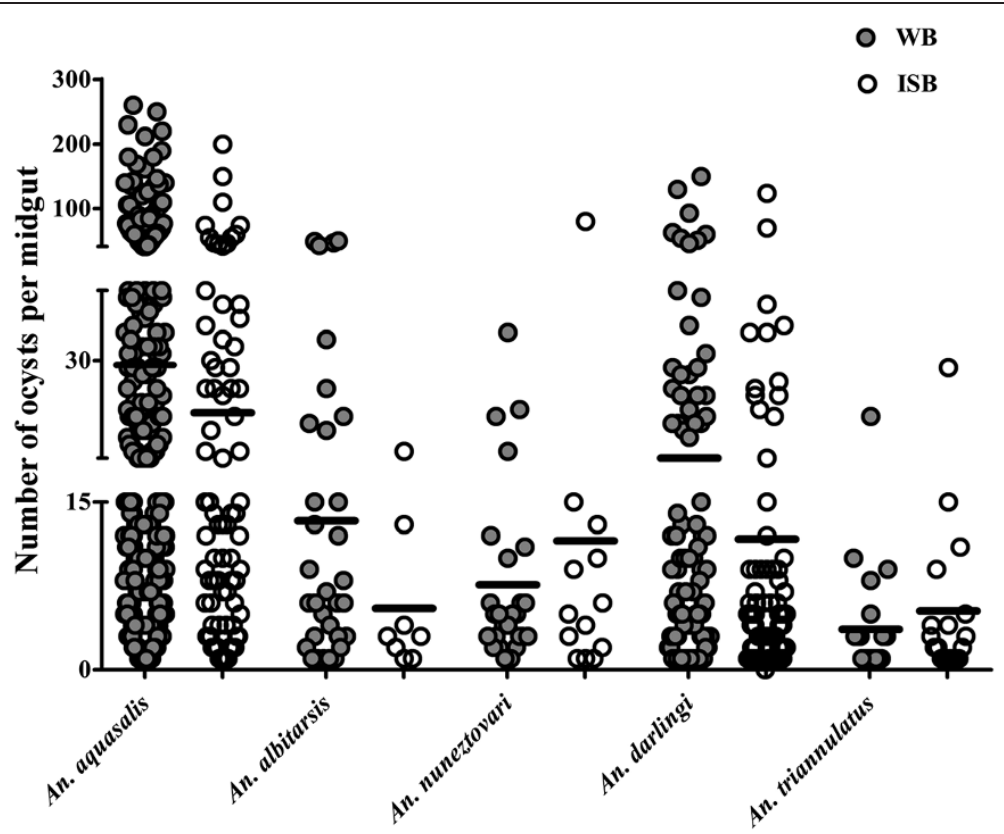

Figure 2 Comparison of the median numbers of Plasmodium vivax oocysts of WB-infected and IBS-infected Anopheles species from the Brazilian Amazon.

considered the main malaria vector in the Brazilian Amazon, and all three species showed high quantity of oocysts, being that the highest one was found in $A n$. aquasalis. These results confirm that the membranefeeding assay is as efficient as direct feeding on human skin when it comes to the study of Plasmodium infection on mosquito vectors.

Anopheles darlingi in Amazon area is more abundant during the late wet season and early dry season, while the other species are more abundant during the early dry season $[44,67]$. Similar situation occurs in Manaus region (personal observation). During the time period when $A n$. darlingi was in high abundance, An. albitarsis s.l. and An. nuneztovari s.l. were in low abundance. When the abundance of An. darlingi was low, An. albitarsis s.l. and An. nuneztovari s.l. abundance increased. This dynamics in species succession is a very important factor for maintenance of malaria transmission, and can present difficulties for malaria control in this region due to susceptibility of all studied species to $P$. vivax infection [68].

Here, it was demonstrated that An. darlingi, An. albitarsis s.l., An. nuneztovari s.l., and An. triannulatus s.l. field populations, and the laboratory-colonized An. aquasalis are susceptible to $P$. vivax under laboratory conditions. All of the studied species might be sporadic competent vectors in nature, although there was a generalized high proportion of uninfected mosquitoes. However, infection rates were much higher than those reported in nature for the five species examined. As determined by the ELISA technique, based on the use of species-specific anti- sporozoite monoclonal antibodies, Amazonian mosquito populations had different $P$. vivax infection rates: An. darlingi ranged from 0.3 to 9.3\%; An. albitarsis s.l. from 0.4 to 5.2\%; An. nuneztovari s.l. from 0.3 to $1.1 \%$; An. triannulatus s.l. $0.2 \%$ and An. aquasalis from 0.3 to $1.3 \%$ [15,18,20-25,27,69-71]. Since this study used blood infected with gametocytes that was offered to mosquitoes, higher infection rates were expected, but variable infectivity in the same setting of gametocytaemia was observed. Differences in infectivity of the different blood samples could be due to a combination of variables, such as, gametocyte maturity, gametocyte gender ratio, different $P$. vivax genotypes, immune factors in patient sera, and host response mechanisms, all of which could alter gametocyte infectivity [27,48,72-74].

The number of oocysts has little importance in malaria epidemiology since most infected mosquitoes found in nature only possesses a few oocysts [75]. The degree of anthropophily in nature is probably the most important factor to determine vector capacity [76]. In sites around Manaus, Brazil, An. darlingi is known to be strongly anthropophilic and endophilic, and population of this species occurs through the year. Anopheles albitarsis s.l. was shown to be a very susceptible species to $P$. vivax, and these results agree with results obtained in other Brazilian Amazonian states of Roraima, Pará, Amapá and Rondônia [15,16,19,70]. However, Klein and collaborators considered An. albitarsis s.l. a dubious malaria vector because of the low number of oocysts, zoophilic behavior and seasonal distribution [44]. Like An. darlingi 

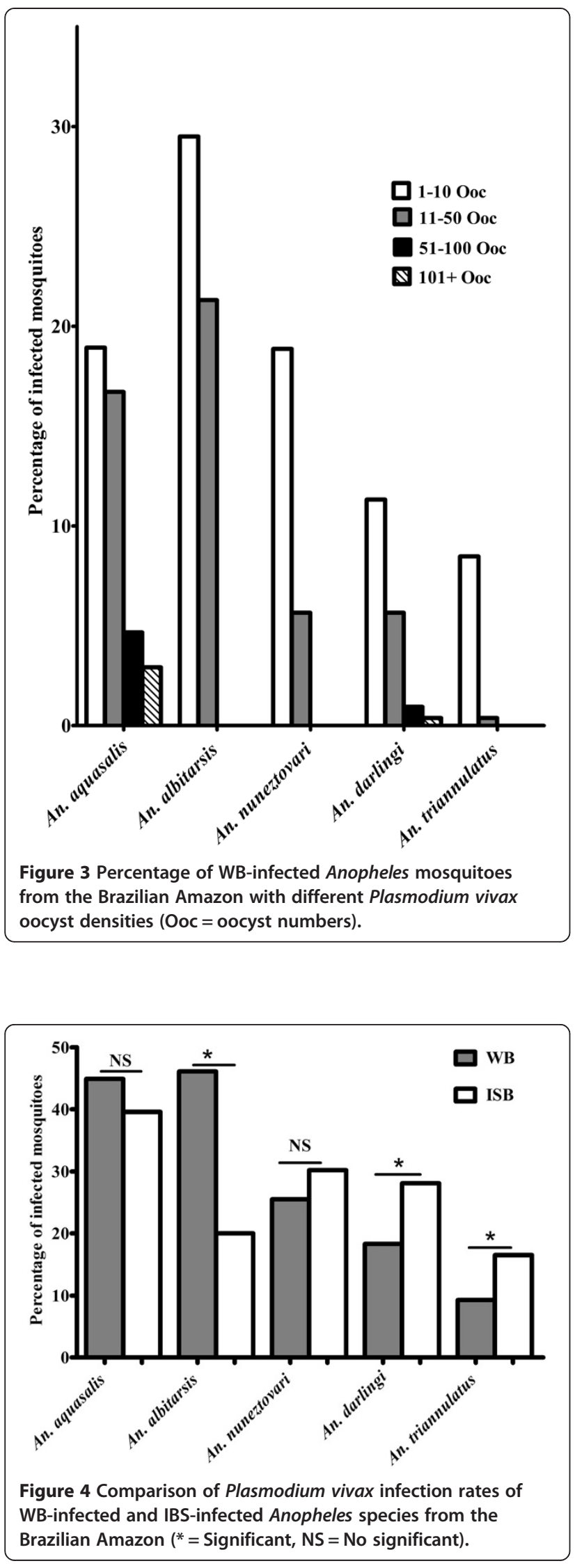

and An. albitarsis s.l., An. aquasalis showed a high susceptibility to $P$. vivax. The high level of susceptibility of An. aquasalis to $P$. vivax indicates the value of using this species in studying New World malarial parasite vectorinteraction. Unlike An. darlingi, An. aquasalis is well adapted to colonization in the laboratory.

Anopheles nuneztovari s.l. also showed a high infection rate, although not statistically different to $A n$. darlingi, it was significantly different to An. albitarsis s.l.. Oocyst numbers in An. nuneztovari s.l. were lower than in $A n$. darlingi and An. albitarsis s.l., although the mean number of oocysts was not significantly different between these species. Anopheles nuneztovari s.l. is considered an important malaria vector in some South American countries [30,31]; however, for others, this species is not considered a malaria vector because natural infections are rarely observed and when they are, infection rates are very low $[18,23,24]$. The results presented here clearly suggest the high potential of An. nuneztovari s.l. as a vector of malaria, which could be considered a risk depending on its density in a given area. In the Manaus area for example, An. nuneztovari s.l. is probably an important species for malaria transmission, because of its high feeding and infection rates observed in laboratory. The population of this species was found in high densities in localities around Manaus where An. darlingi is also abundant [18]. On the other hand, although An. triannulatus s.l. became infected with $P$. vivax in the experiments described here, this species had significantly the lowest infection rates and mean number of oocysts compared with the other species studied. These observations reinforce the conclusion that An. triannulatus s.l. is not an important malaria vector in the Amazon region $[15,16,44,68]$.

Except for An. albitarsis s.l. and An. aquasalis, mosquito infection rates were increased after blood serum inactivation. Blood serum factors have been shown to influence the ability of $P$. vivax gametocytes to infect mosquitoes in experiments in which patient plasma was replaced with $P$. vivax-naïve sera or plasma $[46,66]$. Infection in these two mosquito species does not appear to be strongly related to host immune factors. Resistance to Plasmodium infection in An. albitarsis s.l. and An. aquasalis may be more strongly associated with intrinsic factors related to the mosquito's own immune system, which could respond more effectively to destroy Plasmodium infections. Future studies should include evaluation of $P$. vivax strain variability on mosquito susceptibility and both intra- and interspecific variation in mosquito immune responses to Plasmodium infection.

The results also indicate that the quantity of gametocytes are positively correlated with the infection rate and the number of oocysts formed, but when results were analyzed by individual species only $A n$. darlingi and $A n$. 
aquasalis had a positive correlation between the quantity of gametocytes and the other two variables. However, according to Klein and collaborators there was no correlation between the number of $P$. falciparum gametocytes and the mean number of oocysts formed in An. darlingi, although, in general, low numbers of circulating gametocytes resulted in few infected mosquitoes [17]. Distinct results could be related to observational methods for verifying the quantity of gametocytes, as determined by light microscopy, which does not predict $P$. vivax transmission to mosquitoes [77].

\section{Conclusion}

Development of novel malaria control strategies includes methods aimed at disrupting parasite development in the mosquito vector. Studying natural vector-parasite interactions, as opposed to model systems, is critical to the development of strategies that can ultimately be used in the field. These studies are made difficult in cases where mosquito vectors cannot be colonized in the laboratory. Such is the case with many of the vectors in South America, including the main vector $A n$. darlingi, which has not been colonized after several efforts by distinct research groups (personal observation). Only $A n$. aquasalis, the main vector in coastal Brazil, has been established and maintained in the laboratory. This study established baseline data for key transmission parameters showing that in laboratory, $P$. vivax infection of colonized An. aquasalis had an infection rate of $44.8 \%$ with a mean oocyst count of 29 per infected individual. It is possible now to begin using this system to explore mosquito immune response to $P$. vivax infection [57-59].

\section{Competing interests}

The authors declare that they have no competing interests.

\section{Authors' contributions}

CMRV, FACP, RS, PFPP, NFCS, WPT, and MVGL conceived and designed the experiments; CMRV, KMC, RS, FACP, EVS, and JBPL: field collection and laboratory procedures; CMRV and TJl: data analysis; CMRV, PFPP, TJI, WMM, FACP, WPT, MVGL, and NFCS: data interpretation and manuscript preparation. This manuscript is a part of the PhD thesis developed by CMRV and supervised by PFPP. PFPP is a senior visiting researcher at the Foundation of the Tropical Medicine Dr. Heitor Vieira Dourado in Manaus (FMT-HVD). PFPP, NFCS and MVGL are productivity fellows of the Brazilian Council for Scientific and Technological Development (CNPq). All authors read and approved the final version of this article.

\footnotetext{
Acknowledgements

To the technicians of the Foundation of the Tropical Medicine Dr. Heitor Vieira Dourado (FMT-HVD) namely: Iria Cabral Rodrigues and Sara Gisele Maia da Silva for rearing mosquitoes and membrane-feeding assays; also acknowledgement for patient recruitment, blood collection and malaria thick smear preparation to Wellington Silva and Maria Raimunda da Costa; and José Eckner Alves Lessa for smear evaluation for malaria diagnoses. We would like to thank the technicians from District Health Posts of Puraquequara and Ramal do Brasileirinho, namely Gelsoney Paz Procópio, Edmar de Oliveira Valente, Joab Nascimento and Aldo Rodrigues. The authors are grateful to Ricardo Mota and Diego Leite for their help in the fieldwork and to Carlos Praia, Gervilane Ribeiro and João Bosco for mosquito identification. We would especially like to thank all the innumerable unnamed malarial patients for donating their blood samples, without whom this research project would not be possible.
}

\section{Financial support}

This study was partially funded by Bill \& Melinda Gates Foundation (TransEpi Study) and by the following Brazilian agencies: Foundation of the Institute Oswaldo Cruz (FIOCRUZ), Strategic Programme for Supporting Health Research (PAPES V), Brazilian Council for Scientific and Technological Development (CNPq), Minas Gerais State Research Support Foundation (FAPEMIG) and Amazonas State Research Support Foundation (FAPEAM). CMRV received PhD scholarships from FAPEAM.

\section{Author details}

'Instituto Leônidas e Maria Deane, Fundação Oswaldo Cruz - Amazonas, Rua Teresina, 476, Adrianópolis, 69057-070 Manaus, AM, Brazil. nstituto Oswaldo Cruz, Fundação Oswaldo Cruz, Rio de Janeiro, Brazil. ${ }^{3}$ Instituto Nacional de Pesquisas da Amazônia, Manaus, AM, Brazil. ${ }^{4}$ Ministerio da Saúde, Núcleo Amazonas/Fundação de Vigilância em Saúde, Manaus, AM, Brazil. ${ }^{5}$ Fundação de Medicina Tropical Dr. Heitor Vieira Dourado, Manaus, AM, Brazil. ${ }^{6}$ Universidade Federal de Mato Grosso, Cuiabá, MT, Brazil. ${ }^{\circ}$ Universidade do Estado do Amazonas, Manaus, AM, Brazil. ${ }^{8}$ Centro de Pesquisas René Rachou, Fundação Oswaldo Cruz-Minas Gerais, Av. Augusto de Lima, 1715, CEP 30190-002 Belo Horizonte, MG, Brazil.

Received: 20 October 2013 Accepted: 17 December 2013 Published: 21 December 2013

\section{References}

1. WHO: WHO global malaria programme: world malaria report 2013. Geneva: World Health Organization; 2013.

2. Ministério da Saúde, Sistema de vigilância em Saúde: Situação epidemiológica da malária no Brasil, 2000 a 2011. Bol Epidemiol 2013, 44:1-16.

3. Alexandre MA, Ferreira CO, Siqueira AM, Magalhães BL, Mourão MP, Lacerda MV, Alecrim M: Severe Plasmodium vivax malaria, Brazilian Amazon. Emerg Infect Dis 2010, 16:1611-1614.

4. Costa FT, Lopes SC, Albrecht L, Ataíde R, Siqueira AM, Souza RM, Russell B, Renia L, Marinho CR, Lacerda MV: On the pathogenesis of Plasmodium vivax malaria: perspectives from the Brazilian field. Int J Parasitol 2012, 42:1099-1105.

5. Lacerda MV, Mourão MP, Alexandre MA, Siqueira AM, Magalhães BM, Martinez-Espinosa FE, Filho FS, Brasil P, Ventura AM, Tada MS, Couto VS, Silva AR, Silva RS, Alecrim MG: Understanding the clinical spectrum of complicated Plasmodium vivax malaria: a systematic review on the contributions of the Brazilian literature. Malar J 2012, 11:12.

6. Raposo CCBS, Santos JB, Santos GMC, Gonçalves EGR, Silva AR: Plasmodium vivax malaria: related factors to severity in the State of Maranhão, Brazil. Rev Soc Bras Med Trop 2013, 46:67-72.

7. Price RN, Tjitra E, Guerra CA, Yeung S, White NJ, Anstey NM: Vivax malaria: neglected and not benign. Am J Trop Med Hyg 2007, 77(6):79-87.

8. Baird JK: Neglect of Plasmodium vivax malaria. Trends Parasitol 2007, 23:533-539.

9. Tjitra E, Anstey NM, Sugiarto P, Warikar N, Kenangalem E, Karyana M, Lampah DA, Price RN: Multidrug-resistant Plasmodium vivax associated with severe and fatal malaria: a prospective study in Papua, Indonesia. PLoS Med 2008, 5:e128.

10. Price RN, Douglas NM, Anstey NM: New developments in Plasmodium vivax malaria: severe disease and the rise of chloroquine resistance. Curr Opin Infect Dis 2009, 22:430-435.

11. Deane L: Malaria vectors in Brazil. Mem Inst Oswaldo Cruz 1986, 81:5-14.

12. Zimmerman $\mathrm{RH}$ : Ecology of the malaria vectors in the Americas and future direction. Mem Inst Oswaldo Cruz 1992, 87:371-383.

13. Sinka ME, Rubio-Palis Y, Manguin S, Patil AP, Temperley WH, Gething PW Boeckel TV, Kabaria CW, Harbach RE, Hay SI: The dominant Anopheles vectors of human malaria in the Americas: occurrence data, distribution maps and bionomic précis. Parasit Vectors 2010, 3:72.

14. Sinka ME, Bangs MJ, Manguin S, Rubio-Palis $Y$, Chareonviriyaphap T, Coetzee M, Mbogo CM, Hemingway J, Patil AP, Temperley WH, Gething PW, Kabaria CW, Burkot TR, Harbach RE, Hay SI: A global map of dominant malaria vectors. Parasit Vectors 2012, 5:69.

15. Arruda M, Carvalho MB, Nussenzweig RS, Maracic M, Ferreira AW, Cochrane $\mathrm{AH}$ : Potential vectors of malaria and their different susceptibility to Plasmodium falciparum and Plasmodium vivax in Northern Brazil identified by immunoiassay. Am J Trop Med Hyg 1986, 35:873-881. 
16. Oliveira-Ferreira J, Lourenço-de-Oliveira R, Teva A, Deane LM, Daniel-Ribeiro $C T$ : Natural malaria infections in anophelines in Rondonia State Brazilian Amazon. Am J Trop Med Hyg 1990, 43:6-10.

17. Klein T, Lima JBP, Tada M, Miller R: Comparative susceptibility of anopeline mosquitoes in Rondonia, Brazil, to infection by Plasmodium vivax Am J Trop Med Hyg 1991, 45:463-470.

18. Tadei WP, Thatcher BD: Malaria vectors in the Brazilian Amazon: Anopheles of subgenus Nysorhynchus. Rev Inst Med Trop Sao Paulo 2000, 42:87-94.

19. Silva-Vasconcelos A, Kató MYN, Mourão EN, Souza RTL, Lacerda RNL, Sibajev A, Tsouris P, Póvoa MM, Momen H, Rosa-Freitas MG: Biting indices, hostseeking activity and natural infection rates of Anopheline species in Boa Vista, Roraima, Brazil from 1996 to 1998. Mem Inst Oswaldo Cruz 2002, 97:151-161.

20. Povoa M, Conn JE, Schlichting CD, Amaral JCOF, Segura MNO, Silva ANM, Santos CCB, Lacerda RNL, Souza RTL, Galiza D, Santa Rosa E, Wirtz RA: Malaria vectors, epidemiology, and the re-emergence of Anopheles darlingi in Belem, Pará, Brazil. J Med Entomol 2003, 40:379-386.

21. Povoa M, Souza RTL, Lacerda RNL, Santa Rosa E, Galiza D, Souza JR, Wirtz RA, Schlichting CD, Conn JE: The importance of Anopheles albitarsis $\mathrm{E}$ and Anopheles darlingi in human malaria transmission in Boa Vista, state of Roraima, Amazonian Brazil. Mem Inst Oswaldo Cruz 2006, 101:163-168.

22. Santos RL, Sucupira IM, Lacerda RN, Fayal Ada S, Póvoa MM: Entomological survey and infectivity during malaria outbreak in the Anajás municipality, Pará State. Rev Soc Bras Med Trop 2005, 38:202-204.

23. Santos RL, Padilha A, Costa MD, Costa EM, Dantas-Filho Hde C, Povoa MM: Malaria vectors in two indigenous reserves of the Brazilian Amazon. Rev Saude Publica 2009, 43:859-868.

24. Galardo AKR, Arruda M, Couto A, Wirtz R, Lounibos LP, Zimmerman RH: Malaria vector incrimination in three rural riverine villages in the Brazilian Amazon. Am J Trop Med Hyg 2007, 76:461-469.

25. Rocha JAM, Oliveira SB, Póvoa MM, Moreira LA, Krettli AU: Malaria vectors in areas of Plasmodium falciparum epidemic transmission in the Amazon region, Brazil. Am Trop Med Hyg 2008, 78:872-877.

26. Galvão ALA, Damasceno RG, Marques AP: Algumas observações sobre a biologia dos anofelinos de importância epidemiológica em Belém do Pará. Arq Higen 1942, 12:51-110.

27. Silva ANM, Santos CCB, Lacerda RN, Machado RLD, Póvoa MM: Susceptibility of Anopheles aquasalis and An. darlingi to Plasmodium vivax VK210 and VK247. Mem Inst Oswaldo Cruz 2006, 101:547-550

28. Laubach HE, Validum L, Bonilla JA, Agar A, Cummings R, Mitchell C, Cuadrado RR, Palmer CJ: Identification of anopheles aquasalis as a possible vector of malaria in Guyana, south America. West Indian Med J 2001, 50:319-321.

29. Hiwat H, Issaly J, Gaborit P, Somai A, Samjhawan A, Sardjoe P, Soekhoe T, Girod R: Behavioral heterogeneity of Anopheles darlingi (Diptera: Culicidae) and malaria transmission dynamics along the Maroni River Suriname, French Guiana. Trans R Soc Trop Med Hyg 2010, 104:207-213.

30. Rubio-Palis $Y$, Wirtz RA, Curtis CF: Malaria entomological inoculation rates in Western Venezuela. Acta Trop 1992, 52:167-174.

31. Hayes J, Calderon G, Falcon R, Zambrano V: Newly incriminated anopheline vectors of human malaria parasites in Junin Department, Peru. J Am Mosq Control Assoc 1987, 3:418-422.

32. Orjuela LI, Herrera M, Erazo H, Quiñones ML: Anopheles species present in the department of Putumayo and their natural infectivity with Plasmodium. Biomedica 2013, 33:42-52.

33. Montoya-Lerma J, Solarte YA, Giraldo-Calderón Gl, Quiñones ML, Ruiz-López F, Wilkerson RC, González R: Malaria vector species in Colombia: a review. Mem Inst Oswaldo Cruz 2011, 106:223-238.

34. Benarroch El: Studies of malaria in venezuela. Am J Hyg 1931, 14:690-693.

35. Chadee DD, Kitron U: Spatial and temporal patterns of imported malaria cases and local transmission in Trinidad. Am J Trop Med Hyg 1999, 61:513-517.

36. Berti J, Zimmerman R, Amarista J: Spatial and temporal distribution of anopheline larvae in two malarious areas in Sucre State, Venezuela. Mem Inst Oswaldo Cruz 1993, 88:353-362.

37. Shahabuddin M, Kaslow DC: Biology of the development of Plasmodium in the mosquito midgut: a molecular and cellular view. Bull Inst Pasteur 1994, 92:119-132.

38. Sinden RE: Excystment by sporozoites of malaria parasites. Nature 1974, 52:314.
39. Beier JC: Malaria parasite development in mosquitoes. Annu Rev Entomol 1998, 43:519-543.

40. Gamage-Mendis AC, Rajakaruna R, Weerasinghe S, Mendis C, Carte R, Mendis KN: Infectivity of Plasmodium vivax and $P$. falciparum to Anopheles tessellatus; relationship between oocyst and sporozoite development. Trans R Soc Trop Med Hyg 1993, 87:3-6.

41. Sinden RE, Alavi $Y$, Raine JD: Mosquito - malaria interactions: a reappraisal of the concepts of susceptibility and refractoriness. Insect Biochem Mol Biol 2004, 34:625-629.

42. Gouagna LC, Mulder B, Noubissi E, Tchuinkam T, Verhave JP, Boudin C: The early sporogonic cycle of Plasmodium falciparum in laboratory-infected Anopheles gambiae: an estimation of parasite efficacy. Trop Med Int Health 1998, 3:21-28

43. Vaughan JA: Population dynamics of plasmodium sporogony. Trends Parasitol 2006, 23:63-70.

44. Klein TA, Lima JB, Tang A: Vector incrimination and effects of antimalarial drugs on malaria transmission and control in the Amazon basin of Brazil. Mem Inst Oswaldo Cruz 1992, 87:393-397.

45. Hurd H, Carter V, Nacer A: Interactions between malaria and mosquitoes: the role of apoptosis in parasite establishment and vector response to infection. CTMI 2005, 289:185-218.

46. Bousema T, Dinglasan RR, Morlais I, Gouagna LC, Warmerdam T, AwonoAmbene PH, Bonnet S, Diallo M, Coulibaly M, Tchuinkam T, Mulder B, Targett G, Drakeley C, Sutherland C, Robert V, Doumbo O, Toure Y, Graves PM, Roeffen R, Sauerwein R, Birkett A, Locke E, Morin M, Wu Y, Churcher TS: Mosquito feeding assays to determine the infectiousness of naturally infected Plasmodium falciparum gametocyte carriers. Plos One 2012, 7:e42821.

47. Guttery DS, Holder AA, Tewari R: Sexual development in Plasmodium: lessons from functional analyses. PLoS Pathog 2012, 8:e1002404.

48. Abeles SR, Chuquiyauri R, Tong C, Vinetz JM: Human host-derived cytokines associated with Plasmodium vivax transmission from acute malaria patients to Anopheles darlingi mosquitoes in the Peruvian Amazon. Am J Trop Med Hyg 2013, 88:1130-1137.

49. Han YS, Thompson J, Kafatos FC, Barillas-Mury C: Molecular interactions between Anopheles stephensi midgut cells and Plasmodium berghei: the time bomb theory of ookinete invasion of mosquitoes. EMBO J 2000, 19:6030-6040.

50. Gupta L, Kumar S, Han YS, Pimenta PFP, Barillas-Mury C: Midgut epithelial responses in different mosquito-Plasmodium combinations: the actin cone zipper model of epithelial repair in Aedes aegypti. Proc Natl Acad Sci USA 2005, 102:4010-4015.

51. Pimenta PF, Touray M, Miller L: The journey of malaria sporozoites in the mosquito salivary gland. J Eukaryot Microbiol 1994, 41:608-624.

52. Jaramillo-Gutierrez G, Rodrigues J, Ndikuyeze G, Povelones M, Molina-Cruz A, Barillas-Mury C: Mosquito immune responses and compatibility between Plasmodium parasites and anopheline mosquitoes. BMC Microbiol 2009, 30:154.

53. González-Lázaro M, Dinglasan RR, Hernández-Hernández Fde L, Rodríguez MH, Laclaustra M, Jacobs-Lorena M, Flores-Romo L: Anopheles gambiae croquemort SCRBQ2, expression profile in the mosquito and its potential interaction with the malaria parasite Plasmodium berghei. Insect Biochem Mol Biol 2009, 39:395-402.

54. Carvalho SC, Martins Junior AJ, Lima JB, Valle D: Temperature influence on embryonic development of Anopheles albitarsis and Anopheles aquasalis. Mem Inst Oswaldo Cruz 2002, 97:1117-1120.

55. Arruda ME, Rios Rl, Arantes PC, Oliveira AC, Nascimento LP: Manutenção em laboratório de Anopheles albitarsis e Anopheles aquasalis por copula induzida. Mem Inst Oswaldo Cruz 1982, 77:89-91.

56. Silva ANM, Santos CCB, Lacerda RN, Santa Rosa EP, Souza RTL, Galiza D, Sucupira I, Conn JE, Povoa ME: Laboratory colonization of Anopheles aquasalis (Diptera: culicidae) in Belem, Para, Brazil. J Med Entomol 2006, 43:107-109.

57. Bahia AC, Kubota MS, Tempone AJ, Pinheiro WD, Tadei WP, Secundino NF, Traub-Csekö YM, Pimenta PF: Anopheles aquasalis infected by Plasmodium vivax displays unique gene expression profiles when compared to other malaria vectors and plasmodia. PLoS One 2010, 5:e9795.

58. Bahia AC, Kubota MS, Tempone AJ, Araújo HR, Guedes BA, Orfanó AS, Tadei WP, Ríos-Velásquez CM, Han YS, Secundino NF, Barillas-Mury C, Pimenta PF, Traub-Csekö YM: The JAK-STAT pathway controls Plasmodium vivax load in early stages of Anopheles aquasalis infection. PLOS Negl Trop Dis 2011, 5:e1317. 
59. Bahia AC, Oliveira JH, Kubota MS, Araújo HR, Lima JB, Ríos-Velásquez CM, Lacerda MV, Oliveira PL, Traub-Csekö YM, Pimenta PF: The role of reactive oxygen species in Anopheles aquasalis response to Plasmodium vivax infection. PLoS One 2013, 8:e57014.

60. Faran ME, Linthicum KJ: A handbook of the Amazonian species of Anopheles (Nyssorhynchus) (Diptera: Culcidae). Mosa Syst 1981, 13:1-81.

61. Gorham JR, Stojanovich CJ, Scott HG: Clave ilustrada para los anofelinos de Sudamérica oriental. Atlanta: Communicable Disease Center, United States Public Health Service; 1967.

62. Conover WJ: Practical nonparametric statistic. New York: Wiley; 1999.

63. Hollander ME, Wolfe DA: Nonparametric statistical methods. Nova Jersey: Wiley; 1999.

64. Klein T, Tada M, Lima JBP: Infection of Anopheles darlingi fed on patients with Plasmodium falciparum before and after treatment with quinine or quinine plus tetracycline. Am J Trop Med Hyg 1991, 44:604-608.

65. Alves FP, Gil LH, Marrelli MT, Ribolla PE, Camargo EP, Silva LH: Asymptomatic carriers of Plasmodium spp. as infection source for malaria vector mosquitoes in the Brazilian Amazon. J Med Entomol 2005, 42:777-779.

66. Bharti A, Chuquiyauri R, Brouwer KC, Stancil J, Lin J, Llanos-Cuentas A, Vinetz JM: Experimental infection of the neotropical malaria vector Anopheles darlingi by human patient-derived Plasmodium vivax in the Peruvian Amazon. Am J Trop Med Hyg 2006, 75:610-616.

67. Klein T, Lima JBP: Seasonal distribution and biting patterns of Anopheles mosquitoes in Costa Marques, Rondonia, Brazil. J Am Mosa Control Assoc 1990, 6:700-707.

68. Deane LM, Daniel Ribeiro C, Lourenço de Oliveira R, Oliveira-Ferreira J, Guimarães AE: Study on the natural history of malaria in areas of the Rondonia state-Brazil and problems related to its control. Rev Inst Med Trop Sao Paulo 1988, 30:153-156.

69. Couto AA, Calvosa VA, Lacerda R, Castro F, Santa-Rosa E, Nascimento JM: Controle da transmissão da malária em área de garimpo no Estado do Amapá com participação da iniciativa privada. Cad Saude Publica 2001, 17:897-907.

70. Póvoa M, Wirtz R, Lacerda R, Miles M, Warhurst D: Malaria vectors in the municipality of Serra do Navio, State of Amapá, Amazon region, Brazil. Mem Inst Oswaldo Cruz 2001, 96:179-184.

71. Martins-Campos KM, Pinheiro WD, Vítor-Silva S, Siqueira AM, Melo GC, Rodrigues IC, Fé NF, Barbosa M, Tadei WP, Guinovart C, Bassat Q, Alonso PL, Lacerda MV, Monteiro WM: Integrated vector management targeting Anopheles darlingi populations decreases malaria incidence in an unstable transmission area, in the rural Brazilian Amazon. Malar J 2012, 11:351.

72. Gonzalez-Ceron L, Rodríguez MH, Entel JC, Villarreal C, Kain KC, Hernandez JE: Differential susceptibilities of Anopheles albimanus and Anopheles pseudopunctipennis to infections with coindigenous Plasmodium vivax variants VK210 and VK247 in Southern Mexico. Infect Immun 1999, 67:410-412.

73. Oliveira-Ferreira J, Pratt-Riccio LR, Arruda M, Santos F, Ribeiro CT, Goldberg AC, Banic DM: HLA class II and antibody responses to circumsporozoite protein repeats of $P$. vivax (VK210, VK247 and $P$. vivax-like) in individuals naturally exposed to malaria. Acta Trop 2004, 92:63-69.

74. Souza-Neiras WC, Luciane M, Storti-Melo LM, Cassiano GC, Couto VSCA, Couto ARA, Soares IS, Carvalho LH, Cunha MG, Póvoa MM, Herrera S, Herrera MA, Rossit ARB, Carareto CMA, Machado RLD: Research Plasmodium vivax circumsporozoite genotypes: a limited variation or new subspecies with major biological consequences? Malar J 2010, 9:178

75. Adak T, Singh OP, Das MK, Wattal S, Nanda N: Comparative susceptibility of three important malaria vectors Anopheles stephensi, Anopheles fluviatilis, and Anopheles sundaicus to Plasmodium vivax. J Parasitol 2005, 91:79-82.

76. Nanda N, Joshi H, Subbarao SK, Yadav RS, Shukla RP, Dua VK, Sharma VP: Anopheles fluviatilis complex: host feeding patterns of species $\mathrm{S}, \mathrm{T}$, and U. J Am Mosq Control Assoc 1996, 12:147-149.

77. Sattabongkot J, Maneechai N, Rosenberg R: Plasmodium vivax: gametocyte infectivity of naturally infected Thai adults. Parasitology 1991, 102:27-31.

doi:10.1186/1475-2875-12-460

Cite this article as: Rios-Velásquez et al:: Experimental Plasmodium vivax infection of key Anopheles species from the Brazilian Amazon. Malaria Journal 2013 12:460.

\section{Submit your next manuscript to BioMed Central and take full advantage of:}

- Convenient online submission

- Thorough peer review

- No space constraints or color figure charges

- Immediate publication on acceptance

- Inclusion in PubMed, CAS, Scopus and Google Scholar

- Research which is freely available for redistribution 